International Research Journal of Management, IT \& Social Sciences
Available online at https://sloap.org/journals/index.php/irjmis/
Vol. 6 No. 5, September 2019, pages: 303 308
ISSN: 2395-7492
https://doi.org/10.21744/irjmis.v6n5.777

\title{
Integrating Collaborative Learning in Cyclic Learning Sessions to Promote Students' Reading Comprehension and Critical Thinking
}

\begin{abstract}
Keywords:
collaborative;

comprehension;

integrating;

learning;

reading;

\author{
Nengah Dwi Handayani ${ }^{a}$ \\ Ida Bagus Nyoman Mantra ${ }^{b}$ \\ I Nyoman Suwandi ${ }^{\mathrm{c}}$
}

Received: 27 March 2019

Accepted: 31 July 2019

Published: 30 September 2019

\section{Article history:}

(1)
\end{abstract}


learning creates an active exchange of ideas within students in their groups and develops students' learning willingness and motivation (Jacobs \& Tan, 2015; Felix-Aguelo, 2017).

Collaborative learning encourages students to express themselves to other students and actively communicate to gather and utilize information to achieve the desired learning goal (Lin, 2019). Meanwhile, teachers can provide some help and eventually cater to scaffolding activities to enrich students' independence in learning (Chen, 2013). This indicates that collaborative learning has been shown to have a remarkable impact on students' development in a number of areas and build up their social skills (Feri1 \& Erlind, 2014). Students' social skills may also develop as an impact of learning and working collaboratively (Pang et al., 2018). Moreover, collaborative learning helps students learn deeply to attain higher thinking skills (Rokhaniyah, 2016). However, special skills are also required in conducting collaborative learning. Well-Planned collaborative learning enables to have effective communication between peers, peer evaluation, problem-solving, and the possibility that students begin to teach each other to maximize their capability in learning (Togatorop, 2015).

Understanding the importance of collaborative learning, this study was focused on enhancing students' reading comprehension to solve the learning problems encountered by the students in reading comprehension. This is because reading is one of the most essential language skills (Togatorop, 2015; Krashen, 2013; Suryasa et al., 2017). Through reading, students obtain a great number of knowledge and information to enrich their prosperity in life. However, there are still many students who found reading comprehension is not an easy task to do. It is an activity that involves students' interaction in the form of visual input of language (La Hanisi et al., 2018). Moreover, reading comprehension is usually used for such kinds of purposes like reading for general and specific information, textual meaning and textual references. Because of the cases, teaching reading comprehension to the students is very important since it is a great source of learning (Reynolds, 2015).

Everyone has a way to comprehend and understand the information that they want to get from the reading texts (Shih, \& Reynolds, 2015). Many of them still really struggle in comprehending the reading texts due to some obstacles that hindrance their comprehension. This may include the poor ability in micro and macro linguistic features or the lack of reading strategies. It is a complex activity that involves both perceptions and thought. Reading consists of two related processes; word recognition and comprehension (Reynolds, 2015). Readers typically make use of background knowledge, vocabulary, grammatical, knowledge, experience with text and other strategies to help them understand written text (Lin, 2019; Barrot, 2016; Macías et al., 2018).

Some students perceive that reading is a boring activity. The boredom can lead the students to have low motivation in doing the reading activity. Consequently, teachers should pay attention to how to make reading comprehension activities more amusing and optimally understandable. Generally, during silent reading, students do not have the chance to do something which helps them reach a rapid comprehension. Through the application of the right learning strategy and utilization of interesting activities and challenging learning materials, students may find reading activity is an encouraging thing to do (Chen, 2013). Moreover, teachers should continually assess the students in order they achieve higher learning achievement (Widiastuti \& Saukah, 2017).

One effective way to teach reading comprehension is through collaborative learning. It is an activity in which students work together with each other to do a task and to achieve a predetermined learning goal. It is a recursive activity where two or more people work together to realize shared goals, this is more than the intersection of common goals are seen in nature by sharing knowledge learning and building consensus (Rimor et al., 2010). Most collaboration requires leadership, although the form of leadership can be social within a student group (Feri1 \& Erlind, 2014). In particular team works collaboratively can develop students' skills in dealing with other people.

Collaborative learning has been implemented successfully in diverse wide-ranging classrooms. It could be assumed that collaborative learning is a great reading strategy for students (Rokhaniyah, 2016). It is unique in its emphasis on structuring peer discussion through the use of cooperative learning roles and procedures and encourages students to be active in inquiring, comprehending text and concepts, developing higher thinking to achieve the learning goals (Roselli, 2016). To ensure students have comprehension and ability in learning and eventually they can promote their learning, teachers should appropriately assess the students (Widiastuti, 2018). Therefore, by doing complete appropriate prose of learning through collaborative learning students may build their critical thinking skills.

Considering the phenomenon as described above and the use of collaborative learning in English language teaching as revealed by some researchers (La Hanisi et al., 2018; Rokhaniyah, 2016; Togatorop, 2015; Jacobs \& Tan, 2015), it is important to conduct an in-depth study to improve students' reading comprehension by employing collaborative learning. This study is a classroom clinical learning activity conducted intensively to gradually improve students' reading comprehension and build up critical thinking, develop their communicative as well as social skills. Moreover, the study was conducted as a part of positive action undertaken as a reaction to the result of the preliminary study 
conducted to the students in which the mean figure of their pre-test was really low. Teachers, in this case, felt responsible to help students find an effective strategy in order that they can achieve the predetermined learning standard. This is the prime aim of conducting this study to the students in the English language classroom.

\section{Materials and Methods}

The subject of this study was a group of EFL students. One class was chosen as the subject of the study. They were chosen as the subject of the study because their ability in reading comprehension as indicated by initial reflection was still very low. Therefore, an immediate and appropriate teaching-learning process needs to be carried out to solve the problem. This study was classroom action research consisted of cyclical processes in which in every learning session there were four interconnected activities such as planning, action, observation, and reflection.

In the planning, the researcher prepared the instructional planning for each session before the present study was conducted in the classroom. In action, the researcher did the teaching and learning process. Meanwhile, in the observation, the researcher carefully observed the learning activities. In this step, the researcher observed the subjects' attitudes and behavior toward the teaching and learning process to see the improvement of the subjects. In reflection, the researcher analyzed the result of the post-test and the result of observation. The teaching and learning process was divided into two cycles. Each cycle consisted of two learning sessions to enhance students' reading comprehension through the integration of collaborative learning.

\section{Results and Discussions}

\subsection{Results}

In this classroom action research, the data were collected by administering pre-test, post-test, and questionnaire. The aim of administering the pre-test was to examine the subjects' pre-existing ability in reading comprehension before the treatment was given. Furthermore, the post-test was used in order to see the extent to which the strategy can be used to improve the subjects' ability in reading comprehension and critical thinking.

Pre-cycle

In the pre-cycle, an initial reflection was conducted by doing an interview with the English lecturers who taught reading comprehension at the selected class. The interview was intended to reveal how the students' learning and what strategies that are usually used in teaching reading, and then observation was also conducted. The interview indicated that the lecturers merely employed conventional learning methods in teaching reading in which students were commonly asked to read the reading texts for about 20 minutes and then followed by assigning the students to answer 10 questions and some exercises related to reading presented in the classroom. It is very rarely innovative learning methods that have been introduced in the classroom.

On the completion of the interview, several direct classroom observations were conducted to directly observe how the learning activities were carried in the classroom. Observation aimed to find out the real problems faced by the subjects. Based on the observations, the students found difficulty in reading comprehension especially in identifying general information, specific information, recognizing the textual meaning and textual reference. Moreover, the learning activities of reading comprehension were not really conducted to ensure students gain a high comprehension of reading text.

Furthermore, a pre-test was carried out to know the pre-existing ability of the subject in reading comprehension before the teaching and learning process. The learning activities were started with the administration of pre-test in the form of short answer questions consisting of 20 test items. The tests were constructed to measure students' reading comprehension, which was constructed to see the students' pre-existing ability in reading comprehension. The result of the pre-test showed that the students' reading comprehension was very poor, in which there were no subjects who could achieve the minimum passing grade. It showed that the subjects' reading comprehension needed urgently to be improved.

The mean figure of the pre-test as an initial reflection was 5.50. This figure was considered to be very low if it is compared with the minimum passing grade which has to be passed by the students. Thus, to improve the subjects'

Handayani, N. D., Mantra, I. B. N., \& Suwandi, I. N. (2019). Integrating collaborative learning in cyclic learning sessions to promote students' reading comprehension and critical thinking. International Research Journal of Management, IT and Social Sciences, 6(5), 303-308. https://doi.org/10.21744/irjmis.v6n5.777 
reading comprehension, collaborative learning was integrated into reading classes. The learning sessions were carried out in two cycles to give sufficient learning opportunities for the students in learning reading comprehension, consequently to ensure the learning improvement in reading comprehension and critical thinking, learning cycles were conducted intensively.

\section{Cycle 1}

The teaching cycle was carried out based on the result of the pre-test in which the score of the subject really below the standard minimum passing grade. Thus, an improvement action was planned by integrating collaborative learning as an effort to improve students' reading comprehension and critical thinking. This cycle was divided into 2 sessions. Each session consisted of four activities namely planning, action, observation, reflection. The teaching sessions were prepared for 90 minutes for each session. For the first teaching session, the reading exercises for the first session were developed based on the text as indicated by the learning syllabus for the semester program.

After designing the lesson plan, teaching action was carried out. In each teaching action, there were three main activities namely pre-activity, whilst activity, and post-activity. In pre-activity, the teacher arouses students' prior knowledge and link up the students' knowledge with the upcoming learning material. While-activity is the main activity of the learning process, meanwhile, post-activity is the concluding activity of learning. The main activity was started by asking the students to write down 10 statements concerning what they already knew about the text. They then asked to read them aloud. In addition, prior to reading the text, students were asked to answer 10 questions related to reading the text.

Then, a post-test was administered in the post-activity of the lesson at the end of the second learning session. The students were asked to answer 20 questions related to the reading text being learned. The result of post-test 1 showed that students' reading comprehension and critical thinking improved considerably.

In reflection, the researcher analyzed the result of the post-test and the result of observation. Based on the classroom observation, it showed that students were really active to participate in all learning activities. Additionally, the mean figure for the post-test result was 70.50. Based on the result of these sessions, it was decided to continue this study to the second cycle.

Cycle 2

The second cycle was also conducted in four interconnected activities which were the same as the steps in the first cycle, namely planning, action, observation, and reflection. However, there were some elaborations and revisions of the learning activity. In planning, the lesson plan was revised from the lesson plan in the first cycle. The revision was made to make the second cycle more interesting for the subjects.

In the second cycle, students assigned to be actively engaged in pairs and group learning activities. They were asked to seriously discuss their reading assignments in pairs and discussed them in groups. These types of activities enhanced students' reading skills more quickly as well as their social skills. The result of the classroom observation also indicated that students learning in pairs and groups made the students really active in learning.

In addition, the worksheet for the post-test was administered at the end of the second cycle. In this activity, the post-test was administered at the end of session 2 which consisted of 20 questions in the form of a short answer task. The mean figure for the second teaching cycle was 8.50. This indicated there was significant improvement achieved in post-test 2 as all students achieved the minimum passing grade. It meant that the use of collaborative learning in reading comprehension was very effective. Moreover, the result of the questionnaire showed the responses of the subjects were positive.

\subsection{Discussions}

Collaborative learning exceeds cooperative activity because it involves collaboration in learning to promote better learning achievement. Collaborative learning can also help students to foster more meaningful knowledge when compared to individual learning. In addition, by carrying out activities and collaborative learning projects indirectly skills such as how to communicate will be learned by students. Collaboration can be done in large groups or groups of four or five students. The results of the study showed the advantages of collaborative learning, including being able to elevate the learning outcomes of groups and individuals that are more directed to metacognitive reading skills and the 
emergence of new ideas to solving problems. In addition, classes that are collaboratively managed are more motivated, have a curious nature, the occurrence of helping others and competing healthily.

The present study which made use of collaborative learning in teaching reading comprehension obvious has a significant degree of benefit to students reading comprehension improvement. The data analysis which established the finding of the present class action study showed the effectiveness of collaborative learning in improving the students' reading comprehension. The mean score of the initial reflection or pre-test scores obtained by the subjects under study out the mean figure of 5.50. This mean figure clearly showed that the pre-existing reading comprehension of the students was relatively low.

The result of the data analysis of the reflection or post-test scores in the first cycle showed the increasing mean figures. The mean figure obtained by the subject under study for each cycle was much higher than the result of the initial reflection or pre-test. The mean figure for the first cycle was 70.50 which showed that the reading comprehension improved considerably they had been taught through collaborative learning. The result of the data analysis of the reflection scores obtained by the students in the post-test in the second cycle was 80.50 showed an increasing mean figure. The mean figure obtained by the students for each cycle was convincingly much higher than the mean figure of initial reflection scores.

There was a significant difference in the mean figure between the first cycle and the second cycle. The mean figure of the first cycle and the second cycle was 10 points differences. The significant difference of the mean figure suggested that the teaching reading in the second cycle through collaborative learning could be remarked to be more effective than the first cycle. This was due to the fact that the second cycle was accordingly revised by taking into account the weakness of the students found in the first cycle. Based on the finding of the questionnaire above, the result of the data analysis from the administration of the questionnaire was considered as additional Supporting data. The proportional percentage figures of the total response of the questionnaire for items A, B, C, and D indicated that $70 \%$ of the subjects strongly agreed, $25 \%$ agreed, $5 \%$ did not have an opinion, and $0 \%$ disagreed on the implementation of collaborative learning. This result showed a positive changing attitude and motivation of the students in learning reading comprehension through collaborative learning. These findings answered the research problem that the students' reading comprehension and critical thinking could be improved through collaborative learning.

Collaborative learning is not just working together between students in an ordinary group, but a learning activity collaboratively to solve problems together to achieve certain goals. In achieving certain goals, students work together with friends to determine the problem-solving strategies assigned by the teacher. A small group of students discusses to find a way out, make a joint decision. Students' discussions create a feeling that the issues being discussed together are shared and owned by all group members.

\section{Conclusion}

The purpose of this study was to improve the students' reading comprehension and critical thinking through the integration of collaborative learning. The present classroom action study was conducted due to the poor ability of the students in reading comprehension as indicated by the result of the preliminary study. In this classroom action study, the students' improvement in reading comprehension could be seen by comparing the students' mean score of the pretest, post-test in the first cycle and the second cycle. The study showed that collaborative learning was really effective for students reading comprehension and critical thinking. Moreover, it was found that collaborative learning could improve students' motivation and interest in learning reading comprehension. Therefore, English teachers are suggested to carefully carry out collaborative learning to enhance students' reading comprehension.

\section{Conflict of interest statement}

The authors declared that they have no competing interests.

\section{Statement of authorship}

The authors have a responsibility for the conception and design of the study. The authors have approved the final article.

\section{Acknowledgments}

The authors would like to thank the editor of IRJMIS for their valuable time, support and advice in completing the current study.

Handayani, N. D., Mantra, I. B. N., \& Suwandi, I. N. (2019). Integrating collaborative learning in cyclic learning sessions to promote students' reading comprehension and critical thinking. International Research Journal of Management, IT and Social Sciences, 6(5), 303-308. https://doi.org/10.21744/irjmis.v6n5.777 


\section{References}

Barrot, J. S. (2016). ESL learners' use of reading strategies across different text types. The Asia-Pacific Education Researcher, 25(5-6), 883-892. https://doi.org/10.1007/s40299-016-0313-2

Chen, Y. (2013). The possibility of applying YouTube to motivate learning autonomy. Journal of International Education Research, 9(3), 207. https://doi.org/10.19030/jier.v9i3.7877

Felix-Aguelo, R. (2017). Enhancing students' language competencies through collaborative learning. In Online Proceedings of the International Conference: DRA.

Feri, Z. O., \& Erlinda, R. (2014). Building Students' Learning Autonomy through Collaborative Learning to Develop Their Language Awareness. Proceedings of ISELT FBS Universitas Negeri Padang, 2, 518-523.

Jacobs, G. M., \& Shan, T. H. (2015). Advancing Learner Autonomy in TEFL via Collaborative Learning. Online Submission.

Krashen, S. (2013). Reading and Vocabulary Acquisition: Supporting Evidence and Some Objections. Iranian Journal of Language Teaching Research, 1(1), 27-43.

La Hanisi, A., Risdiany, R., \& Sulisworo, D. (2018). The use of WhatsApp in collaborative learning to improve English teaching and learning process. International Journal of Research, 7(1), 29-35. https://doi.org/10.5861/ijrset.2018.3004

Lin, S. F. (2019). Students' Attitudes towards Learning English Vocabulary through Collaborative Group Work versus Individual Work. Journal of Education and Learning, 8(4), 93-111.

Macías, E. I. P., Cedeño, H. A. C., \& Chávez, G. M. R. (2018). Importance of Improving Resilience in TeachingLearning Process of Students with Disabilities. International Research Journal of Management, IT and Social Sciences, 5(2), 120-128.

Pang, C., Lau, J., Seah, C., Cheong, L., \& Low, A. (2018). Socially Challenged Collaborative Learning of Secondary School Students in Singapore. Education Sciences, 8(1), 24. https://doi.org/10.3390/educsci8010024

Reynolds, B. L. (2015). A mixed-methods approach to investigating first-and second-language incidental vocabulary acquisition through the reading of fiction. Reading Research Quarterly, 50(1), 111-127. https://doi.org/10.1002/rrq.88

Rimor, R., Rosen, Y., \& Naser, K. (2010). Complexity of social interactions in collaborative learning: The case of online database environment. Interdisciplinary Journal of E-Learning and Learning Objects, 6(1), 355-365.

Rokhaniyah, H. (2016). The Implementation of Collaborative Learning to Enhance the Students' Critical Thinking In Writing. At-Ta'dib, 11(1). http://dx.doi.org/10.21111/at-tadib.v11i1.627

Roselli, N. D. (2016). Collaborative Learning: Theoretical Foundations and Applicable Strategies to University. Journal of Educational Psychology-Propositos y Representaciones, 4(1), 251-280.

Shih, Y. C., \& Reynolds, B. L. (2015). Teaching adolescents EFL by integrating Think-Pair-Share and reading strategy instruction: A quasi-experimental study. RELC Journal, 46(3), 221-235. https://doi.org/10.1177\%2F0033688215589886

Suryasa, I. W., Prayoga, I. G. P. A., \& Werdistira, I. (2017). An analysis of students motivation toward English learning as second language among students in Pritchard English academy (PEACE). International journal of social sciences and humanities, 1(2), 43-50. https://doi.org/10.29332/ijssh.v1n2.36

Togatorop, E. (2015). Teaching writing with a web based collaborative learning. International Journal of Economics and Financial Issues, 5(1S), 247-256.

Widiastuti, I. A. M. S. (2018). Teachers' classroom assessment and grading practices. In SHS Web of Conferences (Vol. 42, p. 00052). EDP Sciences. https://doi.org/10.1051/shsconf/20184200052

Widiastuti, I. A. M. S., \& Saukah, A. (2017). Formative assessment in efl classroom practices. Bahasa dan Seni: Jurnal Bahasa, Sastra, Seni, dan Pengajarannya, $45(1), \quad$ 50-63. http://journal2.um.ac.id/index.php/jbs/article/view/677/419 